\title{
Communication and political identity formation: Dubrovnik's first ambassadors to the Sublime Porte
}

\author{
Valentina Zovko
}

Review article

UDK 341.71(497.584Dubrovnik)"14"

\begin{abstract}
The first diplomatic missions from Dubrovnik to the Sublime Porte played an important role in forming the identity of their city. Ambassadors from Dubrovnik were empowered to represent their city during crucial moments in the Ottoman westward expansion. The success of their missions influenced the position the city had under new circumstances characterized by constant shifts in the balance of power.

This essay is focused on oral declarations by Ragusan ambassadors, which can be seen as an attempt to define, describe, and typify the community they are authorized to represent. Although these statements were used primarily to achieve various pragmatic aims, at the same time they can be perceived as an expression of the qualities of the city-state. Their messages reflected their beliefs, traditions, and customs of their culture in correlation with the specific conditions in which they functioned. Their choices depended on assessments of their efficiency. However, sometimes their missions did not end with the desired outcome because their system of values did not correspond to that of an Islamic culture. Nevertheless, over time the initial confusion and concerns were eventually alleviated by the practical experience they acquired.

An analysis of the verbal communication between Dubrovnik's ambassadors and the Porte, from the establishment of formal diplomatic relations to the acceptance of a tributary relationship, facilitates an examination of changes in the way they expressed their identity through verbal arguments
\end{abstract}


and how they manipulated said arguments-in other words, how they wielded propaganda and ideology. In that sense, this verbal communication by the ambassadors is viewed as performativity that not only conveys a message but actively participates in its construction.

Keywords: Dubrovnik, diplomacy, identity, Ottoman Empire, $15^{\text {th }}$ century

\section{Introduction}

At the beginning of August 1430, Dubrovnik's authorities reached the decision to send their first official diplomatic mission to the Ottoman government, known as the Porte. ${ }^{1}$ The selected ambassadors had to face a number of challenging tasks dictated by the political context of the day. The instructions confirmed by the Senate, which the ambassadors were obliged to follow, clearly outlined the objectives of Dubrovnik's diplomacy before the Porte to preserve their freedom, secure commercial privileges, seek the sultan's protection and ensure the welfare of the state and its people. The achievement of these vital goals relied on assertions that underpinned more or less conscious self-presentation; in other words, the political "speech acts" and identity "speech acts" pertaining to community were identical on many occasions.

The purpose of this study is to examine speech acts which expressed different discourses on the city's "collective identity" as an important factor in establishing its relationship to "the Other". Even though there had been certain reciprocal insights into each other's "realities", there were still many gaps in the relationship between the two society which needed to be bridged. This was particularly vital at that moment when the city of Dubrovnik had to assume the best possible position vis-à-vis the expanding Ottoman Empire. An analysis of the instructions given to Dubrovnik's eleven diplomatic missions to the Porte, preserved in the archival series Litterae et Commissiones Levantis (Lettere di Levante), vol. X-XVI, makes it possible to discern the verbal strategies used by the government to construct the city's identity. The missions took place between 1430 and 1458, when the government pledged their "servitude" to the Ottoman

\footnotetext{
${ }^{1}$ When, in 1430, Dubrovnik declared war against Bosnian Duke Radoslav Pavlović, who was one of the sultan's vassals, the earlier attempts of the City authorities to delay official diplomatic representation to the Sublime Porte became untenable. For context see: Truhelka (1917: 179-184). A basic overview of Ottoman-Ragusan relations for the period covered by this study is Božić (1952).
} 
Empire and pledged to send a yearly tribute to the sultan (Stojanović 1934: 233; Nedeljković 1970: 390).

Yet undeniably, remarkable research has been conducted in the study of different strategies for the collective self-representation of the Ragusan Republic in the medieval and Renaissance periods. Lovro Kunčević recently published his doctoral thesis dedicated to the three major discourses on Ragusan identity. Its origins, statehood, and frontiers are studied from abroad array of sources, including historiography, literature and diplomatic correspondence, as well as civic rituals and visual monuments (Kunčević 2015). His significant, impressive, and systematic study of declarations about Ragusan civic identity reveals a crucial point: the specific discourses used when Ragusans spoke about their city-state at the Sublime Porte had a long tradition. Their long-lasting presence in various documented instances is of paramount importance to understanding the strategies behind the decisions to choose particular statements about city-state features in spatial, cultural, social, political, religious, and ethnic frameworks. Certain rhetorical conventions used to speak about the "collective identity of the City" were mentioned only once at the Sublime Porte while others gained the status of topoi. Those statements recognized by their importance can be detected in Vesna Miovićs research into the Ragusan diplomatic contacts with the Ottomans in the early modern period (Miović-Perić 1998; Miović 2003). Finally, the value of more limited studies of some of the statements about city's features (e.g., the city`s Epidaurian origins) by Zdenka Janeković, are also noteworthy (Janeković Röemer 1998).

Although this field of study has taken deep root, this essay is an attempt to reconstruct the expressed features concerning collective identity preserved in the orations of Ragusan envoys dispatched to the Sublime Porte in the relevant period. The core of these issues is the motive underlying the selection of certain discourses about city-state's identity, and its acceptance by the Ottoman ruling elite, which are problems that have not yet undergone scholarly scrutiny.

The first impressions created upon initial contact were important, and they were influenced by reciprocal interests, feelings, impulses, wishes and assumptions pertaining to the Other. It is important to emphasize that the city's identity was neither self-evident nor immutable, and it certainly did not 
represent a faithful depiction of its reality, which was in itself far more complex. ${ }^{2}$ In fact, it was constructed primarily to achieve certain objectives at a given place and time. The ambassadors did not use spoken language only to communicate their thoughts, opinions, beliefs and ideas. Their utterances also revealed the intentions, wishes, and interests of Dubrovnik's government. In that respect, the city's identity was a product of a situational construct and had a clear purpose. It confirmed the special bond between the language, the person who used it, and the reality in which it was used. The ambassador was thus the doer, i.e., he was a part of the reality outside of the language and his objective was to accomplish the tasks with which he was entrusted (Jenkins 2004: 106, 111-112).

The messages about the city's identity consisted of multiple layers and could be transmitted simultaneously via various media. On this occasion, I shall focus only on an analysis of the speech itself and the role it played (Tully 1998: 712; Hampsher-Monk 1998: 42-46; Skinner 2002: 103-127, n. 3). ${ }^{3}$ It was, of course, accompanied by gifts for the hosts, the reputation of the ambassadors, clothing, gestures, and other forms of non-verbal communication. All verbal messages pertaining to Dubrovnik's identity were previously formulated by the government in their instructions, and the task of the ambassadors was to convey them to the letter. However, their influence on the reception of the various verbal strategies they used to present the public identity of the community they represented should not be neglected. The material features of messages include the timber and tone of voice, along with posture and physical gestures that could influence their meaning. Moreover, there was always the possibility that parts of the message could be "lost in translation" since the first of Dubrovnik's ambassadors did not speak the official language of Ottoman administration and had to use interpreters (dragomans). The Ottoman government perceived language primarily as a means of communication, not separation. The absence of a unified language policy in the Empire, in which more than 60 languages were spoken, only confirms this assumption (Karpat 1974: 2; 1984: 189-193; 2002: 676; Dursteler 2014: 14). Regardless of the fact that Ottoman society used multiple languages, Dubrovnik's government began to educate its young diplomats rather early in this process and taught them the language of the Turkish bureaucracy, a

2 Rogers Brubaker and Frederick Cooper have suggested that "identity" as an analytical concept should be abandoned altogether. For their arguments and alternative terms that could be used, see Brubaker et al. (2000).

3 The methodology focused on study of individual "speech acts" in the historical context of their emergence has been suggested by so-called Cambridge school. 
combination of Arabic, Farsi and common "Turkish" (Miović-Perić 2001: 83). Nevertheless, Dubrovnik's first ambassadors needed the services provided by the dragomans, since they were able to model the content and meaning of messages they wished to convey by using their skill, temperament and motivation (Gürçağlar 2004: 241).

Even though a society consists of different individuals, the role of an ambassador as an "objectivised individual" is very important in transmitting messages about the "collective unification" of an entire society. The messages were formed by "imagining the Other". Entire societies were characterized on the basis of a relatively small amount of select information. The "collective identity" of a community conveyed by an individual who was authorized to represent its interests does not correspond to the society as a whole. It can primarily be identified as a single segment of a reaction that occurs when people come into contact with the "Others", who have different views or values specific to their society (Jenkins 2004: 133, n. 4). ${ }^{4}$ The identity verbally constructed by the ambassadors for the purpose of their appearances at the Porte was never a crucial element that could have influenced their countrymen's self-perception. Its main purpose was to define a single specific segment of their identity: the relationship between us and "Others", in which "we" cannot be used to denote the entire society. The formation and perception of the identity should be observed within the space and time in which they occur, since only then does it become clear that identity is a processual and dynamic category that arises from interaction of differences and practical needs.

In that regard, the main task of this paper is to analyse verbal constructions that appeared in the diplomatic discourse for the purpose of conveying messages about the city's identity, the motives behind them, and their modification over time. In doing so, interpretation of abandoned strategies in the verbal presentation of the city's identity imposes itself as a particularly intriguing subject. Furthermore, the paper deals with a comparison of "permanent features" that had different functions in different communities, ${ }^{5}$ and an

\footnotetext{
${ }^{4}$ P. Bordieu coined the term "culturally arbitrary", which implies that similarities and differences between collective identities are socially constructed.

${ }^{5}$ Western European countries did not have accurate information regarding contacts between the Republic of Dubrovnik and the Ottoman Empire during their early diplomatic encounters. This gave the City's government room for manipulation and personation. L. Kunčević pointed out that the government resorted to silence and false representation of their actual relations with the Empire in their contacts with Christian
} 
approach to identity as a relation process in which contact with the "Others" influenced its actual formation.

\section{Only a single mention of the "Epidaurian tradition"}

Dubrovnik's first ambassadors to the Sublime Porte, Petrus de Luccari and Georgius de Goçe, evoked the tradition of Epidaurus, according to which Dubrovnik "as known to everybody, moved from the place where it had stood for over 1,000 years and relocated to where it stands now some 800 years ago." ${ }^{6}$ While the intent of this paper is to analyse the speech acts of the Ragusan ambassadors on the features of the community they were authorized to represent, in order to understand the motives behind the decision to invoke the "Epidaurian origin" in a specific socio-political and cultural context, it should be stressed that this discourse had a long and rich diplomatic tradition in order to request various surrounding territories which allegedly once belonged to the ancient predecessor of their city. At the same time, this ideologeme was used as a source of historical legitimacy and discourse about the origin for both the Ragusan Church and the city's patriciate. ${ }^{7}$ The "Epidaurian myth" was invoked many times, not just for different purposes but also in different political, social and cultural contexts. Therefore, its transformations over time in order to adapt to the republic's specific interests are not surprising. Although the goal of this paper is not to give an overview of usage nor changes in the "Epidaurian tradition", beyond any doubt its longevity and acceptance clearly proves its importance and success in medieval and early modern Ragusan history.

By using this image at the Porte, which served as an explanation of the city's establishment, the people of Dubrovnik displayed the city's values and beliefs. Leaving aside the issue of the historical veracity of the city's foundation, at this point it is more important to point out that the ideas underlying this concept did not have to be accepted as "true" in other communities that nurtured other beliefs, customs, and traditions. The concept was primarily a part of the ideology that the authorities employed to achieve its pragmatic objectives.

Europe, Kunčević(2008: 54-55). The same article has been published in English, Kunčević(2010: 25-69).

${ }^{6}$ State Archives in Dubrovnik (hereinafter: DAD, Lettere di Levante (hereinafter: Lett. di Lev.), ser. 27/1, vol. X, f., 211v, (13 Sept 1430); Ibid, f. 212v (13 Sept 1430).

7 For the Epidaurian heritage in the Ragusan tradition see: Janeković (1998: 31-41); Janeković Römer (1999: 13-56); Kunčević (2015). 
On the other hand, it is worthwhile recalling that the ambassadors sent to the Sublime Porte for the first time were trying to gain the sultan's support in the Ragusan conflict over part of the Konavle region with Bosnian Duke Radoslav Pavlović, who was a vassal to both the Bosnian king and the Ottoman sultan. The decision of the Senate to extol the Epidaurian origin of the city before Murad II should not be perceived solely as a discourse on origins, but rather as an attempt to bolster Dubrovnik's claim over the contested territory which Dubrovnik did not just purchase from the duke previously, but which also once belonged to an ancient predecessor of their city. Actually, the Epidaurian discourse used by the envoys at the Sublime Porte in 1430 was an echo of earlier Ragusan diplomatic attempts to expand their territorial borders over Konavle. In other words, the narrative of the city's earliest history and the rights granted to it as a larger and more important descendant of ancient Epidaurus was not a novel verbal formulation used in diplomatic discourse at the time. It is surely not a coincidence that the same strategy for territorial expansion was previously conveyed to Louis I of Anjou in 1358 and Sigismund of Luxembourg in 1407 and 1411 (Gelcich et al. 1887: 174, 202; Vučetić 1906: 460, n. 8). ${ }^{8}$ In fact, the discourse first appeared in a charter that the Sanković brothers issued to Ragusa in 1391, granting it the territory of Konavle, "which once belonged to Cavtat, where the old city of Ragusa had been situated". After Epidaurus had been abandoned, the territory of Konavle was unjustly seized by neighbouring lords, and therefore the act of the Sanković brothers legitimized what they perceived as "truly just", which was probably an explanation they had heard from the Ragusans themselves (Stojanović 1929: 124, n. 9). ${ }^{9}$

Dubrovnik's perceived origin in the town of Epidaurus was a product of both personal and social knowledge and, as such, it became the only possible and accepted origin within the community. It also served as a confirmation of Dubrovnik's uniqueness when compared to other realities (Rokeach 1972: 124). The result of such a process was a cluster of values and characteristics that the community assigned to itself alone, which acted as a cohesive bond among its members and distinguished it from other social groups. The "Epidaurian tradition" as the foundation of the city's identity was used to convey messages of its importance based on the past which mandated privileged treatment of the community in the present. Although this narrative was one of the most important

\footnotetext{
${ }^{8}$ On this rhetoric, see: Janeković (1998; 31-45); Stulli (2001: 293-294).

${ }^{9}$ For an analysis of this document and its context, see: Mišić (2008: 113-127).
} 
discourses of old Ragusa and surely abundant in semantic meanings, when it came to its applicability to the achievement of vital concerns, Zdenka Janeković has proven that the theory of Epidaurus descent was not accepted even in societies close to Dubrovnik that shared similar cultural symbols (Janeković 1998).Such symbols gained meaning by being recorded due to the efforts of a small social group: Dubrovnik's aristocracy. The government resorted to conventions, agreements and debate, communication and negotiation to have the "Epidaurian tradition" recognized and accepted by others. They demonstrated a fair level of insecurity when they voted on practical decisions regarding the activities of the first ambassadors to the Porte. ${ }^{10}$ In spite of this, it is still difficult to state whether they hoped in advance that actualization of the "Epidaurian tradition" before the Sublime Porte would be sufficient to assure the sultan's confirmation of Dubrovnik's right to the territory of Konavle. To sum up, the discourse about the ancient origin of the city appeared only once in front of the Ottomans. It was an echo of the long-term Ragusan diplomatic tradition which was used much earlier before all of those who had sufficient power to influence Dubrovnik's territorial aspirations over the territory of Konavle. Later diplomatic contacts with the Ottomans have shown that political agreements could be achieved only if they were mutually beneficial, keeping in mind the position one took in the hierarchy of power relations in the given period. ${ }^{11}$

The verbal construction of the city's identity based on its descent from Epidaurus can be explained by considering locution and perlocution as factors of verbal communication (Austin 1962: 101). While the task of the former is to convey a message, the latter refers to convincing, i.e. provoking effects. It should be pointed out that speech which intends to provoke an effect and the actual effect do not have to be congruent. The ambassador's verbal statements had to be convincing in order to be accepted as truthful. If a statement is confirmed by other people, it is considered more likely to be true. This is why the ambassadors did not miss the opportunity to invite the sultan's ambassador Karadža to testify

10 An example that confirms this is the fact that they asked Sandalj Hranić, the duke of Bosnia, for advice regarding Dubrovnik's first diplomatic mission to the Porte, Lett. di Lev., vol. X, f. 209r, (13 Sept 1430); Ibid, f. 211r, (13 Sept. 1430). Moreover, it should be pointed out that the Ottomans had just begun to form their administration and ceremonial procedures when Dubrovnik's ambassadors came to the Porte. Both were codified in the latter half of the 15th century, under the rule of Mehmed II (1432-81), Muslu, (2007:165).

11 Lett. di Lev., vol. XIII, f. 17r, (22 Mar 1441); Ibid, vol. XVI, f. 100v (22 May 1458) 
about what he had seen "with his own eyes" during his stay in the city. ${ }^{12}$ Search for support among the ranks of prominent representatives of the Ottoman political elite was a constant practice in Dubrovnik's diplomacy. It should not be forgotten that at the beginning of the $15^{\text {th }}$ century the Empire underwent significant changes in its governing apparatus, which were the result of promoting distinguished incomers from conquered lands. Their ascent was due to the fact that Ottoman society accorded priority to an individual's competence over his origin. Therefore, it comes as no surprise that Dubrovnik's ambassadors often turned to such individuals in search of friendly advice and assistance. ${ }^{13}$

In the end, the city's "Epidaurian tradition" never detached itself from the community's narrow mentality and, as such, did not become a permanent component of the instructions to the Ragusan envoys sent to the Ottoman Empire. Its usage in 1430 was an isolated case and confirmation that the Epidaurian tradition did not comport with the values of Islamic society. The new situation required a re-definition of the patterns in which Dubrovnik's collective identity was expressed throughout history (Turner 1975: 9). City leaders realized soon enough that they needed a different strategy, a strategy that would be recognized by the Ottomans, whose society valued the balance of power much more than historical roots and rights that emerged from historical tradition. In that sense, the reference made by the ambassadors to good relations between the sultan and their own sovereign, the Hungarian king, ${ }^{14}$ promised to serve as a sound base for building mutual collaboration. Sultan Murad II sent a report to the Mamluk sultan, Al-Ashraf Barsbay (1422-1438) regarding a three-year truce they had signed with the Hungarian king in 1428 . He was reluctant to sign the truce at first, despite Sigismund's pleas. The letter leaves the impression that he wanted to justify his actions to a Muslim ruler of a higher rank, ${ }^{15}$ particularly since both of them were obliged to fight against Christian countries (Muslu 2007: 119).

12 This refers to a purchase agreement whereby Duke Radoslav sold his half of Konavle to the people of Dubrovnik, Lett. di Lev., vol. X, f. 212v (13 Sept 1430).

${ }^{13}$ For instance, Dubrovnik's ambassadors in the Ottoman capital closely cooperated with Mahmud-Pasha Angelović (1420-1474), Lett. di Lev., vol. XIV, ff. 189v-190r, (14 Jan 1458); Ibid, vol. XVI, 191r (no date).

14 Lett. di Lev., vol. X, f. 159v, (18 Jun 1430); Ibid, 211v, 213r-213v, (13 Sept 1430).

${ }^{15}$ At the time, the Mamluks, as descendants of the Abbasids and rulers of Egypt and Syria, played the leading role in protecting the Islam against the Crusaders and Mongols. 
Although Dubrovnik's ambassadors attempted to maintain their discourse unchanged in order to create a widely recognizable identity for the city, it eventually did undergo certain changes. These were made based on their experience and their aim was to achieve results that corresponded to the "cultural landscape" of the society they had entered. The attempt to actualize the borrowed authority of an ancient city in the form of a rather fragile tradition proved to be important to the formation of Dubrovnik's future identity. Still, various topoi they had formulated in order to construct the city's identity had to be adjusted to correspond to actual changes so they could yield success in cultures which differed from the one to which they belonged. The initial diplomatic strategy was premised on the assumption that the "Others" were similar to "us". The unknown was supplemented by imagination. Their initial problems were resolved thanks to the personal experiences of the first ambassadors who shared their knowledge about Ottoman administration, diplomatic protocol, values and customs accepted at the Porte. ${ }^{16}$ In time, their experience became a source of knowledge and the argument about the "Epidaurian tradition" was omitted as pointless in comparison to bribes or other services that Ragusans could provide to the Ottomans as vague gestures of "fidelity", annual tribute and occasional military support (e.g., supplying information, strategic resources or skilled labour) (Nagy et al. 1877: 19-20; Kumrular 2011: 39).

\section{Poverty and freedom - "commonplace" facets of Dubrovnik's identity}

The instructions for Dubrovnik's ambassadors often contained the same verbal constructs used to convey their collective identity. Although at first glance they seem to be only "form without meaning", what should be considered is the value of analyzing them in various communities over a longer duration. Viewed from that perspective, they provide insight into the government's tactics and the manner in which they re-shaped verbal formulations to suit a specific time and place.

The salient features of the city's identity came from its geo-strategic position. At the time, the powerful Ottoman Empire was establishing its rule over the areas close to Dubrovnik's hinterland, so the city exploited its geographical

16 The authorities demanded reports on these matters from their ambassadors, Lett. di Lev., vol. X, f. 211r, (13.9.1430). 
position to emphasize its poverty and thus diminish Ottoman financial expectations. ${ }^{17}$ An identical description of a city "overlooking steep cliffs and surrounded by the sea"18 was used in the West to illustrate Dubrovnik's marginal position, i.e., its function as a Catholic mission among the Patarenes and schismatics that occupied the Balkans. It was described as a righteous city surrounded by infidels who constantly plotted against it (Kunčević 2010a: 185186, n. 19). ${ }^{19}$ Participants in the Council of Basel in 1433 were convinced of it, emphasizing "that the city of Dubrovnik is situated by the sea (and is often battered, shaken and threatened by its waves), on the hardest of rocks and in an infertile area. Even though it is surrounded by sects of infidels and schismatics, it continues to protect the one true faith"(Radonić 1934: 340). Dubrovnik's government repeated this same description of the city, as "situated on a very steep cliff and almost completely surrounded by the sea", in a letter to Sicilian Queen Joan II in 1431. The rest of the letter is also very interesting, since it states that "their neighbours, the Ottomans, spend their days and nights in attempts to use their innate inhuman cunningness to threaten our lives and possessions and rob us of our Republic"(Radonić 1934: 325, 333). This strategy incorporating the image of a poor city continued to be the main weapon in Dubrovnik's diplomatic arsenal even a hundred years afterward. For instance, in 1540 Dubrovnik's ambassador, Serafinus de Zamagna, reported to the Doge of Venice that "the city is situated on infertile ground which cannot guarantee enough food to survive one month". The harshness of the city's position served the ambassador as a convenient introduction to justify its annual tribute to the sultan, which guaranteed the city would survive and continue to faithfully serve the interests of the entire republica christiana. ${ }^{20}$ The purpose of this skilfully constructed argument by the city's leaders was to demonstrate that Dubrovnik's "fealty" and "deference" to the sultan, were, in fact, in the best interests of the entire Christian world. ${ }^{21}$ The city's poverty served a completely different purpose in

\footnotetext{
${ }^{17}$ Lett. di Lev., vol. X, f. 211v, (13 Sept 1430); Ibid, f. 213v-214r, (13 Sept 1430); Ibid, vol. XIII, f. 46v-47r, (2 Oct 1441); Ibid, f. 56r, (15 Dec 1441); Ibid, f. 191v-192r, (no date). The same approach was employed by Ragusan ambassadors to the Sublime Porte after 1458. See: Miović (2003: 201-210).

18 Lett. di Lev., vol. XII, f. 211v, (13 Sept 1430)

19 The same article has been published in English, Kunčević(2013: 37-68).

20 Lett. di Lev., vol. XXII, f. 108r, (14 Feb 1540).

${ }^{21}$ For Ragusan explantations of their relationship with the "infidels", see: Kunčević(2008: 61-66).
} 
1588. Specifically, it was used as a pretext to avoid implementing Church reforms (Kunčević 2010a: 201).

Certain discrepancies in presenting their identity, depending on their audience, can be seen in the example of "Dubrovnik's freedoms", a source of particular pride for the city fathers. ${ }^{22}$ The city's government used the fact that they had given shelter to Serbian despot Đurađ Branković, an enemy of the sultan, ${ }^{23}$ to emphasize their own Christianity, their resistance against Ottoman conquers, and a demonstration of their "sovereignty" (Janeković Rőmer 2007: 75). At the same time, they swore to the sultan that Dubrovnik was his "smallest and most faithful servant". ${ }^{24}$ On two occasions in which the city authorities promised to send an annual "gift" ("tribute") to the Ottomans, in 1442 and 1458, the sultan acknowledged that Dubrovnik and its inhabitants would remain "in their laws and liberties"(Stojanović 1934: 233; Nedeljković 1970: 390).Although, in their speeches the ambassadors referred to Dubrovnik as a "republic" which acknowledged the supreme rule of the Hungarian-Croatian king, ${ }^{25}$ around the mid-15 $15^{\text {th }}$ century the city became ade facto tributary state of the Ottoman Empire. However, the Ragusans did not perceive that status as a sign of their "vassalage". Moreover, in the $16^{\text {th }}$ century they promoted the view according to which tributary status was a result of their free will (Liepopili 1929: 127). Lovro Kunčević persuasively argued that, at least from Dubrovnik's standpoint, their relationship with the Empire was understood as contractual, in other words, "it could be revoked if one of the involved parties did not observe its obligations" (Kunčević 2013a: 98-110).

In the aforementioned examples, diplomatic rhetoric was presented as an ideological weapon that could be adjusted to suit specific audiences. The manipulative use of information on one's identity was intended to provoke emotional reactions in listeners and direct their actions towards the interests of Dubrovnik's government. The strategy of always using the same symbols and altering their function to suit the occasion, depending on the political, social and cultural context, was probably the most prominent feature of the city's government.

22 Lett. di Lev., vol. X, ff. 214v-215r, (13 Sept 1430); Kunčević(2008: 66).

${ }^{23}$ Lett. di Lev., vol. XII, f. 215v, (15 Jul 1441); Božić (1952:86-89).

24 Lett. di Lev., vol. XI, ff. 58v, 59v, (2 Dec 1431); Ibid, f. 154r, (20 Jul 1433)

25 Lett. di Lev., vol. X, ff. 208v, 211v, 213r, (13 Sept 1430); Ibid, vol. XI, 48r, (23 Jul 1430); Ibid, vol. XII, f. 215r, (15 Jul 1440) 


\section{Identity as a relational process}

Although the focal point of this paper is the reconstruction of verbal strategies used for the formation of Dubrovnik's identity, it should be pointed out that the city's identity was a complex phenomenon and that its formation was influenced by a number of components that arose from the actions of its ambassadors, both intentional or unintentional. An aspect that should not be overlooked is that the Ottomans were not passive recipients of the identity constructed by the city's ambassadors. In fact, they actively participated in its formation. The first ambassadors to the Porte found themselves in a position that could be described as "liminal". ${ }^{26}$ Interactions were conducted through both official institutions and personal contacts, with the result that the two cultures intertwined and even imitated each other. The example of Paulus de Ragusa, who taught Sinan-Bey to paint portraits in Istanbul, confirms the exchange of artistic skills between the West and the East (Norton 2013: 11).

The meeting of the two cultures also had negative effects. During their first diplomatic missions in the Ottoman capital, Dubrovnik and its ambassadors were labelled "heretics" and "schismatics" in some Christian countries. ${ }^{27}$ At the beginning of the $16^{\text {th }}$ century, the people of Dubrovnik were perceived as the "new Turks" of the West in neighbouring countries, regardless of the fact that they had always remained faithful to their Christian identity (Janeković Rőmer 2007: 79).

The construction of Dubrovnik's identity at the Porte was a reciprocal process that merged the proclaimed values and the government's beliefs as illustrated in the speeches delivered by its ambassadors with personal features which could be perceived through their unintentional actions and spontaneous behaviour. In the end, rapprochement between Dubrovnik and the Ottoman Empire resulted in a better understanding between the two cultures, which enabled the city's government to make optimal decisions regarding the city's selfpreservation.

\footnotetext{
${ }^{26}$ The concept of liminality was developed by Victor Turner at the beginning of the 20th century. Here it is used to describe the transitional zone/boundary at which different identities, cultures, and traditions meet.

${ }^{27}$ Lett. di Lev., vol. XI, 155r, (20 Jul 1433); Ibid, f. 166v, (5 Oct 1433).
} 


\section{Conclusion}

The construction of Dubrovnik's identity in the speech of its first ambassadors at the Ottoman Porte was primarily directed at acquiring certain rights and privileges for the city. The language they used consisted of a specific vocabulary that did not represent the actual collective identity of the city but rather a means to accomplish the interests of Dubrovnik's government. The city's verbally constructed identity corresponded to the fundamental requirements of the Republic regarding its territory, trading privileges, acquittal of prisoners, and its position in the co-dependent relations of the Middle Ages. Therefore, in this case identification could be perceived as a process generated by interaction in which identity was adapted to correspond to the "Others". Interaction between the two societies can be described as bi-directional, complex, dynamic, and, on occasion, contradictory. In that sense, the construction of the city's identity was never finalized and it never completely corresponded to reality.

In time, the ambassadors came to understand the rules of interaction and the values of the East, which, to an extent, enabled them to predict certain outcomes and select strategies that would ensure their acceptance and recognisability. Certain verbal patterns they had used to express their identity were futile and disappeared over the course of time while others became "commonplace". Moreover, Dubrovnik's ambassadors throughout Europe referred to them quite often, altering their function to suit the occasion, which demonstrates that adaptability was obviously one of the features of the government's identity.

Still, a verbally established identity could not significantly influence the achievement of the government's pragmatic goals. In fact, it mostly depended on the interests of the Ottoman political elite. In time, the ambassadors learned which components of their verbal patterns to omit and which to retain. They also learned how to adapt their speech to correspond to a given situation in order to achieve their objectives and resume cooperation. It should be pointed out that they used words as a means to provoke desired reactions, particularly to gain the trust of the Ottomans.

The authorities in Dubrovnik used verbal constructs to form the city's identity. Their speech served the purpose of achieving the city's foreign-policy objectives when necessary. Nevertheless, on occasion the government's assessment of its validity was proved wrong under different political and social circumstances. It resulted in the abandonment of such verbal constructs, i.e., in 
giving new meaning to old forms to make them more functional within an altered cultural framework. In doing so, the government used both propaganda and ideology. This puts a speech act in relation to the transfer of meaning, which can be manipulated according to its context. Dubrovnik's diplomatic discourse and its messages of collective identity should be analysed as a situational construct with the aim of organizing and producing various forms of knowledge that can be applied in specific political, social, and cultural contexts.

\section{Bibliography}

\section{Primary Sources}

State Archives of Dubrovnik, Litterae et Commissiones Levantis (Lettere di Levante), ser. 27/1, vol. X-XIV, XVI, XXII.

\section{GELCICH ET AL. 1887}

Josip Gelcich and Lájos Thalloczy (eds.), Diplomatarium relationum rei publicae ragusanae cum regno Hungariae, Budapest 1887.

LIEPOPILI 1929

Ante Liepopili, "Dopisi Marojice Kaboge vladi dubrovačkoj," Glasnik dubrovačkog učenog društva "Sveti Vlaho," 1, Dubrovnik 1929, 125-146.

NAGY ET AL. 1877

Iván Nagy and Albert Nyáry (eds.), Magyar diplomaczia iemlékek Mátyáskirály korából 1458-1490, tomus 2, Budapest 1877.

RADONIĆ 1934

Jovan Radonić (ed.), Dubrovačka akta i povelje, I/1, Belgrade 1934.

STOJANOVIĆ 1929

Ljuba Stojanović (ed.), Stare srpske povelje i pisma. book I vol. 1, Belgrade 1929.

STOJANOVIĆ 1934

Stojanović, Ljuba (ed.), Stare srpske povelje i pisma, book I vol. 2, Belgrade 1934.

\section{Secondary Sources}

BOŽıć 1952

Ivan Božić, Dubrovnik i Turska u XIV i XV veku, Belgrade 1952.

BRUBAKER ET AL. 2000

Rogers Brubaker, Frederick Cooper, "Beyond 'Identity'," Theory and Society, 29, Dordrecht 2000, 1-47. 


\section{DURSTELER 2014}

Eric R. Dursteler, "Language and Identity in the Early Modern Mediterranean," in: Mediterranean Identities in the Premodern Era: Entrepôts, Islands, Empires (eds. J. Watkins and K. Reyerson), Surrey Burlington 2014, 35-52.

\section{GÜRÇAĞLAR 2004}

Gürçağlar, Aykut, "Representations of Ottoman Interpreters by Western Painters," Acta Orientalia Academiae Scientiatum Hungaricae, 57/2, Budapest 2004, 231-242.

\section{HAMPSHER-MONK 1998}

Ian Hampsher-Monk, "Speech Acts, Languages or Conceptual History," in: History of Concepts: Comparative Perspectives (eds. I. Hampsher-Monk, K. Tilmans, and F. van Vree), Amsterdam 1998, 37-50.

\section{JANKOVIĆ 1998}

Zdenka Janković, "Stjecanje Konavala: Antička tradicija i mit u službi diplomacije," in: Konavle u prošlosti, sadašnjost i budućnosti. Zbornik radova sa znanstvenog skupa "Konavle u prošlosti, sadašnjosti i budućnosti” održanog u Cavtatu od 25. do 27. studenog 1996. godine, vol. 1, (ed. V.Stipetić), Dubrovnik 1998, 31-44.

\section{JANEKOVIĆ RÖMER 1999}

Zdenka Janeković Römer, Okvir slobode, Zagreb-Dubrovnik 1999.

\section{JANEKOVIĆ RÖMER 2004}

Zdenka Janeković Römer, "Osmanlis, Islam and Christianity in Ragusan Chronicles (16 $6^{\text {th }}-17^{\text {th }}$ Centuries)," in: Tolerance and Intolerance on the Triplex Confinium. Approaching the "Other" on the Borderlands. Eastern Adriatic and Beyond, 1500-1800 (eds. E. Ivetic and D. Roksandić), Padua 2007, 61-79.

\section{JENKINS 2004}

Richard Jenkins, Social identity, London - New York 2004.

\section{KARPAT 1974}

Kemal H. Karpat, The Ottoman State and its Place in World History, Leiden 1974.

\section{KARPAT 1984}

Kemal H. Karpat, "A Language in a Search for Nation: Turkish in the NationState," in: The Emergence of National Languages (ed. A. Scaglione), Ravenna 1984.

KARPAT 2002

Kemal H. Karpat, Studies on Ottoman Social and Political History, Leiden 2002. 
KUMRULAR 2011

Özlem Kumrular, "Dubrovnik: izvor obavijesti između Istoka i Zapada Dubrovnik, Mleci i Visokaporta," in: Tajna diplomacija u Dubrovniku u XVI. stoljeću, (ed. M. Polić Bobić), Zagreb 2011, 38-49.

KUNČEVIĆ 2008

LovroKunčević, "O dubrovačkoj libertas u kasnom srednjem vijeku," Anali Dubrovnik, 46, Zagreb - Dubrovnik 2008, 9-64.

KUNČEVIĆ 2010

Lovro Kunčević, "On Ragusan Libertas in the Late Middle Ages," Dubrovnik Annals, 14, Zagreb-Dubrovnik 2010, 25-69.

KUNČEVIĆ 2010A

Lovro Kunčević, "Retorika granice kršćanstva u diplomaciji renesansnog Dubrovnika," Anali Dubrovnik, 48, Zagreb - Dubrovnik 2010, 179-211.

KUNČEVIĆ 2013

Lovro Kunčević, "The Rhetoric of the Frontier of Christendom in the Diplomacy of Renaissance Ragusa (Dubrovnik)," Dubrovnik Annals, 17, Zagreb - Dubrovnik 2003, 37-68.

KUNČEVIĆ 2013A

Lovro Kunčević, "Janus-faced Sovereignty: The International Status of the Ragusan Republic in the Early Modern Period," in: The European Tributary States of the Ottoman Empire in the Sixteenth and Seventeenth Centuries (eds. G.Kármán and L.Kunčević), Leiden - Boston 2013, 91-121.

KUNČEVIĆ 2015

Lovro Kunčević, Mit o Dubrovniku: diskursi o identitetu renesansnog grada, Zagreb - Dubrovnik, 2015.

MIOVIĆ 1998

VesnaMiović, "Metode dubrovačke diplomacije u kontaktima s Osmanlijama," Zbornik Diplomatske akademije, 3, Zagreb 1998, 243-252.

MIOVIĆ-PERIĆ 2001

Vesna Miović-Perić, "Dragomans of the Dubrovnik Republic: their Training and Career," Dubrovnik Annals, 5, Zagreb-Dubrovnik 2001, 81-94.

MIOVIĆ 2003

Vesna Miović, Dubrovačka diplomacija u Istambulu, Zagreb-Dubrovnik 2003.

MIŠIĆ 2008

Siniša Mišić, "Povelja Beljaka i Radiča Sankovića Dubrovniku," Stari srpski arhiv, 7, Belgrade 2008, 113-127. 
MUSLU 2007

Emire C. Muslu, "Ottoman-Mamluk relations: Diplomacy and Perceptions," (unpublished doctoral thesis), Massachusetts 2007.

NEDELJKOVIĆ 1970

Branislav M. Nedeljković, “Dubrovačko-turski ugovor od 23. oktobra 1458. Godine," Zbornik Filozofskog fakulteta Beograd, 9/1, Belgrade 1970, 363393.

\section{NORTON 2013}

Claire Norton, "Blurring the Boundaries: Intellectual and Cultural Interaction between the Eastern and Western; Christian and Muslim Worlds," in: The Renaissance and the Ottoman World (eds. A. Contadini and C. Norton), Farnham 2013, 3-22.

ROKEACH 1972

Milton Rokeach, Beliefs, Attitudes and Values. A Theory of Organization and Change, San Francisco-Washington D.C.-London 1972.

SKINNER 2002

Quentin Skinner, Visions of Politics. Volume I: Regarding Method, Cambridge 2002.

\section{STULLI 2001}

Bernard Stulli, "Dubrovačke odredbe o Konavlima (I)," in: Bernard Stulli, Studije iz povijesti Dubrovnika. Zagreb 2001, 293-314.

TULLY 1988

James Tully, "The Pen is a Mighty Sword: Quentin Skinner's Analysis of Politics," in: Meaning and Context: Quentin Skinner and his Critics (ed. James Tully), Cambridge 1988, 7-25.

\section{TRUHELKA 1917}

Ćiro Truhelka, "Konavoski rat (1430-1433)," Glasnik Zemaljskog muzeja u Bosni i Hercegovini, 29, Sarajevo 1917, 179-184.

\section{TURNER 1975}

John C. Turner, "Social comparison and social identity: Some prospects for intergroup behaviour," European Journal of Social Psychology, 5/1, Hoboken 1975, 1-34.

\section{VUČETIĆ 1906}

Antonije Vučetić, "Spomenici dubrovački," Srđ, V/9, Dubrovnik 1906, 458464. 